\title{
LAS NUEVAS TECNOLOGÍAS REPRODUCTIVAS, LA VIEJA PATERNIDAD ${ }^{\top}$
}

\author{
The new reproductive technologies, the old paternity
}

\author{
Verena Stolcke* \\ * Catedrática Emérita. Universidad Autónoma de Barcelona \\ verena.stolcke@uab.es
}

\section{Palabras clave}

Nuevas técnicas reproductivas

Eugenesia Identidad genética Feminismo

\section{Keywords}

New reproductive technologies

Eugenics

Genetic identity

Feminism

\section{Resumen}

El artículo realiza un recorrido por la historia de la aplicación de las nuevas tecnologías reproductivas en humanos (nTR), destacando la simultaneidad entre el desarrollo de estas técnicas en los países del norte preocupados por la baja fecundidad y las campañas de control de la natalidad por medio de esterilizaciones involuntarias en el sur pobre. Recoge también debates contemporáneos a la redacción de la primera ley de reproducción asistida española en 1988. Muestra que el proyecto eugenésico acompaña el desarrollo de las nTR y las implicaciones de clase, de raza y, muy especialmente, de género que tiene su desarrollo y aplicación en un contexto de "naturalización" o de "genetización" de la identidad social. A pesar de que, aparentemente, la fecundación por donantes y el nacimiento por fecundación in vitro perturban los cimientos de nociones occidentales de familia, maternidad y paternidad, lo cierto es que en su origen y aplicación estas técnicas buscan aliviar la infertilidad por medio de procurar hijos biológicamente vinculados y fenotípicamente cercanos a sus padres, reforzando la idea bio-genética de la identidad y la filiación.

\section{Abstract}

The article looks over the application of new reproductive technologies in humans (nRT), highlighting the simultaneity of the development of those technologies in the north worried about their low fertility and the campaigns for reproductive control through involuntary sterilizations in the poor south. The text also gathers contemporary debates around the first Spanish law on assisted reproduction of 1988. It shows that the eugenic project accompanies the development of $\mathrm{nRT}$ and the implications it has in terms of class, race and, particularly, of gender in its development and application in a context of "naturalization" or "genetization" of social identity. Although apparently the fecundation through donors and the birth through in vitro fecundation trouble the roots of western notions of family, maternity and paternity, in their origin and application those techniques seek to alleviate infertility by ensuring children biologically linked and phenotypically close to their parents, reinforcing the bio-genetic idea of identity and filiation.

Stolcke, V. (2018). Las nuevas tecnologías reproductivas, la vieja paternidad. Papeles del CEIC. International Journal on Collective Identity Research, vol. 2018/2, papel 193, CEIC (Centro de Estudios sobre la Identidad Colectiva), UPV/EHU Press, http://dx.doi.org/10.1387/pceic.20116

\footnotetext{
${ }^{1}$ Este texto es una reedición del artículo publicado en el libro de Celia Amorós et al. (1987). Mujeres: ciencia y práctica política (pp. 87-129). Madrid: Universidad Complutense, en el que se recogieron las aportaciones de diferentes académicas feministas al Seminario de mismo título organizado por Instituto de Estudios Feministas de la Universidad Complutense de Madrid. Una segunda versión algo más extensa del mismo artículo fue publicada en inglés en: Stolcke, V. (1988). New reproductive Technologies: The old quest for fatherhood. Reproductive and Genetic Engineering, 1, 5-19. Especialmente para esta edición Verena Stolcke ha redactado una posdata que contribuye a enfatizar la actualidad de un texto escrito hace ya tres décadas.
} 
Me parece oportuno iniciar mis reflexiones sobre las implicaciones que tienen las nuevas tecnologías reproductivas (nTR), en especial para nosotras las mujeres, citando a dos autores de los años treinta. Ante los recientes logros de la ciencia y de la técnica en el campo de la procreación humana, sus posturas opuestas resultan proféticas. Ya entonces se preveían las "conquistas" hoy logradas por la tecnología médica de aspectos importantes del proceso reproductivo humano, pero también había quienes nos advertían de los peligros de una ciencia inspirada en valores e intereses sociales específicos.

En 1938 Virginia Woolf escribía en Tres guineas (2014): "Parece que la ciencia no es asexuada: la ciencia es un hombre, es padre, y también está contaminada".

Casi al mismo tiempo, del otro lado del Atlántico, el distinguido biólogo estadounidense marxista H. J. Muller vislumbraba un "mundo feliz" poblado por seres altamente inteligentes y solidarios. Como Muller escribía en 1936, mediante técnicas biológicas tales como la inseminación artificial, el cultivo y almacenamiento de espermas de grandes hombres, la obtención de óvulos para fecundación extracorpórea, la transferencia de embriones y la predeterminación y selección del sexo para eliminar enfermedades genéticas y controlar la tasa sexual, todo ello al servicio de una nueva ciencia eugenésica social, sería posible mejorar la calidad intelectual y moral de los individuos, transformar las relaciones sociales competitivas y abolir las clases:

\begin{abstract}
"Ahora todo esto puede parecer un sueño ocioso. No sólo todo esto es ciertamente factible, sino que sin duda será realizado. Exactamente de qué manera estas aplicaciones de la genética llegarán al hombre puede ser materia de disputa, pero llegar, llegarán. Es inconcebible que el hombre abdique jamás de su dominio, ahora que ha llegado hasta aquí. Ni un mundo ilustrado rechazará para siempre los medios eficaces para su adelanto. No sólo es patente que la mejora genética es posible, sino que es mucho más segura y factible que la conquista definitiva del átomo, del espacio interplanetario o de la naturaleza externa en general... E incluso aunque fracasemos en la conquista de la naturaleza externa, nos habremos conquistado a nosotros mismos" (Muller, 1936: 154-155)².
\end{abstract}

\footnotetext{
${ }^{2}$ La editora se especializaba en libros de autores de izquierda y editó también algunas de las obras de George Orwell. Muller fue un pionero de la genética moderna. Inspirado por la teoría de la herencia de Mendel, contribuyó a la localización cromosómica de muchos
} 
Las nuevas tecnologías reproductivas que Muller proponía estaban explícitamente inspiradas por un proyecto eugenésico. Muller compartía este entusiasmo por las ideas eugenésicas con la mayor parte de los genetistas contemporáneos en Estados Unidos, que resultó ser el terreno más fértil para esta doctrina. Fue, sin embargo, uno de los pocos que adoptó una postura inequívocamente crítica ante la utilización conservadora y fascista de la genética, intentando, en cambio, reconciliar las ideas eugenésicas con una filosofía política y social incluso radical. No obstante, aunque nunca logró demostrar que la inteligencia y los valores morales solidarios fueran hereditarios, no cuestionó en ningún momento la propia teoría ni abandonó los elementos elitistas de ella. Defendía también la liberación de las mujeres del "martirio" de la maternidad involuntaria. Sin un control de nacimientos, estaría condenado al fracaso cualquier programa de "reproducción eugenésica" de una minoría que por él optase acudiendo a bancos de semen donde aquellas mujeres cuyos maridos fuesen estériles se podrian inseminar artificialmente con esperma de hombres excelentemente dotados.

El programa eugenésico de Muller tal vez hoy suene ingenuo y superado. Sin embargo, el empeño casi misionario de Muller por dominar la naturaleza en función de un proyecto social global que a pesar de sus buenas intenciones degradaba a las mujeres, por razones aparentemente biológicas -el infinitamente mayor número de gametos producidos por los hombres permitía una selección incomparablemente más rigurosa en su caso que en el de las mujeres-, a meros instrumentos para mejorar la especie ejemplifica bien el androcentrismo de la ciencia que Virginia Woolf denunciaba ${ }^{3}$.

genes, a la interpretación de enfermedades genéticas y al estudio de mutaciones experimentales inducidas por la aplicación de rayos $X$. Escéptico ante las posibilidades de poner en práctica su doctrina eugenésica progresista en una sociedad capitalista y desencantado con la insensibilidad por el sufrimiento humano en Estados Unidos, en 1933 se trasladó a la Unión Soviética a invitación del Instituto de Genética de Moscú. Pero el dogmatismo político de T.D, Lysenko provocó su oposición y dejó Rusia integrándose como médico en las Brigadas Internacionales, en las que participó en la guerra civil. En 1947 Muller recibió el premio Nobel de Medicina, y en la posguerra denunció con insistencia los efectos deletéreos de la radiación sobre la dotación genética humana. Formó parte de comisiones nacionales e internacionales para el control y la regulación de la energía atómica, y hasta su muerte, en 1967, trabajó en la divulgación de su doctrina eugenésica humanista (Allen, 1970).

${ }^{3}$ Como Muller sugería: "Es fácil demostrar que en el curso de uno o dos siglos sería posible que la mayor parte de la población adquiriese las cualidades innatas de hombres (sic) tales como Lenin, Newton, Leonardo, Pasteur, Beethoven, Omar Khayyám, Pushkin, Sun Yat Sen, 
El caso de Muller no sólo muestra cómo ideas y valores sociales influyen en proyectos científicos, sino que revela una clara conexión entre tecnologías reproductivas y proyectos eugenésicos que está lejos de estar superada.

\section{1. ¿QUÉ HAY DE NUEVO EN LAS NUEVAS TECNOLOGÍAS REPRODUCTIVAS?}

Casi todas las sociedades han ejercido algún tipo de control reproductivo. El control de nacimientos no fue inventado por científicos médicos, sino por las mujeres, aunque raramente gozaran de la libertad de decidir por sí mismas si y cuándo tener un hijo (Gordon, 1976). Sólo a principios del siglo pasado se inicia la medicalización de la procreación. Ante la simplicidad de la técnica de inseminación artificial (IA), que consiste tan sólo en depositar el semen de un hombre en la vagina de una mujer, no sorprende que las primeras inseminaciones artificiales daten ya de hace casi dos siglos. En 1791 el doctor Hunter, de Inglaterra, logró el primer embarazo de una mujer con el semen del marido. En 1804 el doctor Thouret repitió la hazaña en Francia. Inicialmente, esta técnica estaba reservada para casos en que fuera imposible o difícil el coito por incapacidad del marido. La primera condena oficial de la inseminación artificial fue pronunciada por un tribunal de Burdeos en 1880. Se alegaba que esta técnica de fecundación atentaba contra la "ley natural" y la dignidad del matrimonio. En 1897 el Santo Oficio prohibió la técnica por implicar la procreación sin relación sexual y la masturbación, violando así la "ley natural". La oposición de la Iglesia católica parece haber frenado la inseminación artificial en Francia, mientras que se difundía en Estados Unidos, donde el doctor Pancoast había realizado la primera inseminación con semen de donante en 1884 en un caso de azoospermia del marido. En la misma época, el descenso progresivo de la natalidad en este país indicaba la frecuencia de abortos ilegales y del uso de otros medios populares de control de nacimientos ${ }^{4}$.

Mientras que el movimiento antiabortista estadounidense criminalizaba los abortos, se promulgaban también en Estados Unidos las primeras

Marx o incluso que poseyese la combinación de sus facultades varias" (Muller, 1936: 141). Pero se olvida de mencionar, por ejemplo, a Marie Curie, que junto con su marido había descubierto los elementos radiactivos polonio y radium, y que en 1911 había recibido ella sola el premio Nobel de Física.

${ }^{4}$ Para una breve historia de la inseminación artificial: Gordon, 1976 y David, 1985. 
leyes de esterilización obligatoria aplicables a retrasados y enfermos mentales, a los físicamente incapacitados, siendo las víctimas frecuentemente inmigrantes o negros, para mejorar la raza mediante un control de la reproducción (Allen, 1970: 347) ${ }^{5}$.

Con el descubrimiento por Ogino y Knaus, en 1932, del período fértil en el ciclo femenino, la inseminación artificial se tornó infinitamente más eficaz, aunque si se utilizaba semen de donante continuaba siendo considerada como una violación de la dignidad humana. En 1953, Bunge y Sherman lograron el primer embarazo con espermas congelados (conseguido en vacas en 1950). Con ello surgen los primeros bancos de semen en Estados Unidos y se amplía la posibilidad de IA con semen de donante. En la misma época se difundian también ampliamente los anticonceptivos mecánicos y hormonales de uso predominantemente femenino, al menos en los países industrializados.

La IA estaba destinada a resolver casos de esterilidad masculina y a satisfacer el deseo del marido o de la pareja por tener un hijo de la propia "sangre" de ésta. Las nTR, en cambio, tienen como objetivo "aliviar la esterilidad", sobre todo femenina. La fecundación in vitro (FIV) se comenzó a desarrollar a partir de 1950; se aplicó a humanos por primera vez en 1969. En 1978 nace en Inglaterra la primera niña por FIV y transferencia de embriones (TE), logro del médico Steptoe y del biólogo Edwards. En 1984 nace en Los Angeles el primer bebé de probeta estadounidense, y un mes más tarde nace otra niña en Australia, esta vez de un embrión previamente congelado. La profesión médica española tampoco se quedó atrás, pues también en 1984 nace una niña en el Instituto Dexeus de Barcelona, y al año siguiente, un niño en un centro sanitario público de Euskadi. Pero a estas alturas, las nTR han dejado de ser privilegio exclusivo de los países industriales avanzados. En 1984 el doctor Nakamura, de São Paulo (Brasil), logra producir un niño por FIVTE, después de que en los años previos especialistas internacionales como

\footnotetext{
${ }^{5}$ El Estado de Indiana adoptó en 1907 la primera ley de esterilización para débiles mentales y criminales inveterados, y en 1915 otros doce estados habian seguido su ejemplo. Durante los años cincuenta y sesenta, una nueva ola de esterilizaciones involuntarias ocurrió en los estados del sur de Estados Unidos, donde fueron esterilizadas sin su consentimiento numerosas jóvenes y mujeres negras; otras víctimas de tales abusos han sido mujeres indigenas y de origen mexicano, así como muchas mujeres en los países latinoamericanos (Clarke, 1984). Aunque haya mujeres que acudan voluntariamente a hacerse esterilizar, esto generalmente no constituye una opción libremente tomada, por la ausencia de servicios adecuados de planificación familiar y por las condiciones económicas miserables en que viven.
} 
Sherman, Steptoe, Edwards y un equipo australiano habían hecho extensas visitas al país. Las proezas más recientes, sin embargo, son un nacimiento quíntuple por FIVTE en un hospital de Londres, de gemelos producidos con óvulos congelados en Australia y supuestamente un embarazo extrauterino de seis meses en Madrid (Gomez dos Reis, 1985) ${ }^{6}$.

¿Cuáles son, en principio, las indicaciones médicas para la FIV, y cuáles son los procedimientos utilizados? En aproximadamente dos tercios de los casos de esterilidad que pueden ser tratados por FIVTE se trata de parejas en las que la mujer padece de anomalías en las trompas de Falopio. En el tercio restante, la mujer se somete a este procedimiento clínico por factores de esterilidad masculina, tales como problemas inmunológicos o incompatibilidad entre semen y moco del cuello del útero $^{7}$. Existen diferencias clínicas significativas entre la IA y la FIVTE. La IA requiere tan sólo una jeringa para introducir el semen en la vagina de la mujer. La FIVTE, en cambio, es una técnica tanto física como psicológicamente muy onerosa para ella.

En primer lugar, requiere que la mujer sea internada en una clínica, se someta a un intenso tratamiento de hormonas para estimular la ovulación, ya que por razones de eficacia es aconsejable extraer más de un óvulo para fecundación in vitro con el semen del marido recogido mediante masturbación o, en caso de esterilidad de éste, de un donante. La extracción de los óvulos se realiza mediante laparoscopia, que consiste en una punción del abdomen de la mujer a través del ombligo para extraer el líquido folicular con los óvulos bajo anestesia general. Un procedimiento más nuevo consiste en la extracción por vía vaginal mediante punción ecográfica con anestesia local. Una vez fecundados, por lo menos tres embriones son reimplantados a través del cuello del útero en el interior de la cavidad uterina. A partir de aquí comienza la

\footnotetext{
${ }^{6}$ Informe presentado en la Women's Emergency Conference on the New Reproductive Technologies, realizada en Vaellingen (Suecia), del 3 al 8 de julio de 1985; según informa Nature el 20 de febrero de 1986 en "India embraces test-tubes" (Jayaraman, 1986), en la India se ha obtenido recientemente el primer embarazo por FIVTE, después de que tres años antes el Indian Council for Medical Research había aprobado la FIV y había perfeccionado el método aplicándolo a 25 mujeres con trompas de falopio bloqueadas. Para otros nuevos "avances" ver: El País, 31 de marzo, 27 de junio y 5 de julio de 1986.

${ }^{7}$ Dr. Barri Rague, jefe del Servicio de Fertilización Humana del Instituto Dexeus, de Barcelona, ante la Comisión Parlamentaria Especial de Estudio de la Fecundación "in Vitro" y la Inseminación Artificial Humanas (Barri Rague, 1985).
} 
angustiosa espera. ¿Habrán anidado los embriones? (Barri Rague, 1985: 109-110) ${ }^{8}$.

Otra variante es la transferencia intratubárica de gametos, que consiste en depositar los óvulos y el semen en el interior de las trompas de Falopio en la misma intervención quirúrgica de recogida de óvulos. Finalmente, se utiliza también la extracción del embrión aún no implantado del útero de la mujer por medio de flush o "lavado", con transferencia posterior a otra mujer que madura el embrión en su propio útero. La FIVTE produce una mayor incidencia de nacimientos múltiples que embarazos naturales y de partos por cesárea debido al afán de los equipos médicos por obtener "éxitos", lo que redunda en mayor riesgo para la mujer. La FIVTE permite además la manipulación de óvulos y de embriones para donación y para experimentación.

¿Qué hay de verdaderamente nuevo en estas nuevas tecnologías reproductivas? (Duelli Klein, 1985) ${ }^{9}$. En primer lugar, en contraste con la IA, las nTR sirven para "aliviar" la esterilidad femenina sin, no obstante, ofrecer un tratamiento para ella, y además se utilizan también en casos en que la causa es masculina. Así, las nTR ofrecen "soluciones" tecnológicas para problemas cuyas causas, tales como las de la propia esterilidad o del porqué de ese "deseo" por una maternidad propia que motiva a mujeres a someterse a ellas, se dejan de investigar (Crowe, 1985) ${ }^{10}$. En segundo lugar, las nTR implican siempre una extensa manipulación biomédico-técnica y psicológica de la mujer que contrasta con la simplicidad de la IA. En tercer lugar, el desarrollo y los avances en estas técnicas requieren extensa investigación y experimentación realizadas muchas veces con trozos de cuerpos de mujeres como úteros $u$ ovarios extirpados en histerectomías frecuentemente innecesarias (Corea, 1984). Y, finalmente, estas manipulaciones del cuerpo de la mujer son una precondición para "avances" biogenéticos como la donación de seres humanos, la selección del sexo en el embrión, la ectogénesis -la

\footnotetext{
${ }^{8}$ El Instituto Dexeus considera recomendable la transferencia de al menos tres embriones para asegurar la implantación; sin embargo, debido a la dificultad hasta el momento de congelar los embriones sobrantes se han transferido hasta siete "por razones éticas", con lo cual la probabilidad de embarazos múltiples aumenta.

${ }^{9}$ Sugiere que las nTR refuerzan la degradación y la opresión de las mujeres (Duelli Klein, 1985: 65).

${ }^{10}$ Considera las nTR como un technological fix que sólo aparenta "curar" la esterilidad muchas veces causada por complejos factores sociopsicologicobiológicos tales como el estrés, la ansiedad, la relación con la pareja, etc.
} 
producción de vida extracorpórea-, que así se están tornando cada vez más factibles.

Me he detenido en los aspectos en apariencia puramente clínicos de las nTR. Somos nosotras las mujeres quienes constituimos sus objetos privilegiados, pero la fragmentación de la ciencia y el monopolio del saber y de la técnica por los "expertos" nos privan de la información necesaria para que podamos juzgar el alcance que tienen estos "avances" para nuestra integridad como personas. Además, al reducir la esterilidad a un problema puramente médico-técnico, estos "expertos" niegan sus implicaciones sociopsicológicas y políticas, desdeñando las inquietudes específicas que nosotras las mujeres podamos tener ante estas nuevas técnicas ${ }^{11}$.

Los defensores de las nTR suelen justificarlas por razones tanto científicas como humanitarias. El progreso de la ciencia es un bien en sí, puesto que contribuye al bienestar general y a la realización individual. Mediante el control de enfermedades genéticas, estas técnicas contribuirían a mejorar el estado de salud general. Se nos dice además que, al fin y al cabo, nosotras las mujeres las queremos e incluso las merecemos, ya que todas tenemos derecho a un hijo propio. Como proclama el Informe de la Comisión Especial de Estudio de las nuevas tecnologías reproductivas del Parlamento español:

"Asistimos a la aparición y utilización de modernos métodos y procedimientos de procreación, capaces de vencer la esterilidad humana, aunque ya con un campo de actuación mayor, y sin duda alguna exponente de la inteligencia y capacidad creadora del hombre" (Congreso de los Diputados, 1986).

Esta Comisión estaba integrada por seis parlamentarios, entre ellos una mujer. Entre los treinta y seis "expertos" invitados para informar sobre las implicaciones biológicas, genéticas, jurídicas y éticas de las nTR había tan sólo una abogada y una médica. Es igualmente significativo que entre los ocho filósofos y moralistas, convidados para manifestarse sobre aspectos

\footnotetext{
${ }^{11}$ Así, reaccionando ante las críticas de mujeres a las nTR, un médico de la República Federal de Alemania reducía recientemente el cuerpo humano, en el contexto de la reproducción, a un mero "almacén de materia prima": "Oímos decir a un miembro del Parlamento de los Verdes que ella considera que las técnicas de FIV reducen a los cuerpos humanos a 'almacenes de materia prima'. Bueno, si consideramos este término desde una perspectiva neutra, ¿qué más podrían ser los cuerpos humanos en el contexto de la reproducción humana?" (Deutsches Aerzteblatt, 1986: 357).
} 
éticos y morales, cuatro fueran de la Universidad Pontificia de Comillas, uno era catedrático de Derecho Eclesiástico de la Universidad de Navarra y otro especialista en Derecho Canónico (Congreso de los Diputados, 1986). En cambio, una representación de mujeres que pudiese plantear las inquietudes y defender los intereses de las supuestas "beneficiarias" brillaba por su ausencia. Está lejos de mi intención atribuirles a los hombres una insensibilidad esencial para la experiencia de las mujeres y tampoco sugiero que las mujeres, por naturaleza, adoptarian una perspectiva específicamente femenina. Somos todos productos de la sociedad en que vivirnos. Pero, precisamente por esta razón, la exclusión casi total de mujeres de la Comisión, que se plasma además en posturas nítidamente androcéntricas del Informe, es sintomática del menosprecio en que se han tenido los intereses específicos de las mujeres.

En efecto, los expertos que integraron la Comisión se mostraban bastante reticentes en explicitar en detalle los procedimientos clínicos a que tiene que someterse una mujer que participa de un programa de FIVTE, actitud que, si no resultaba de una banalización consciente, por lo menos redundaba en una minimización inconsciente del coste físico y psíquico de estas técnicas.

Pero no sólo es difícil obtener informaciones fidedignas sobre los procedimientos clínicos, sino que hay una manipulación sistemática de las cifras sobre la incidencia en la población de la esterilidad que las nTR deben "vencer" y sobre la eficacia real de estas técnicas en producir niños.

Según las cifras manejadas en el Informe de la Comisión Especial de Estudio, hay un 10 a un 13 por 100 de parejas estériles en edad fértil entre quince a cuarenta y nueve años en España. Sin embargo, es desaconsejado un embarazo antes de los dieciocho años y después de los cuarenta, por razones biológicas. Por otra parte, el doctor Barri, por ejemplo, atribuyó el que la ciencia haya buscado nuevas soluciones técnicas para la esterilidad al hecho de que ésta aparentemente iba en aumento (Congreso de los Diputados, 1985a; 1986: 10906) ${ }^{12}$. Es obvio que cuanto mayor sea la demanda social potencial de estas técnicas reproductivas, tanto más justificadas resultan la experimentación y las inversiones que exigen. El informe parlamentario contiene entre los

\footnotetext{
${ }^{12}$ En octubre de 1985, el mismo Dr. Barri había declarado a la prensa, sin embargo, que la tasa de esterilidad entre parejas en edad fértil se situaba entre el 12 y el 15 por 100 (EI País, 25 de octubre de 1985).
} 
apéndices un cuadro preparado por la Sociedad Española de Fertilidad, en el cual se calcula en 38 a 40 los centros de FIV deseables en el Estado español para satisfacer una demanda potencial de sus servicios de unos 36.000 a 90.000 casos anuales (Congreso de los Diputados, 1986: 173 [cuadro 2]) ${ }^{13}$.

Ya que la FIV está prevista sobre todo para indicaciones femeninas, también es relevante la distribución de la esterilidad por sexo. Así, el informe parlamentario estima en un 60 a 70 por 100 las causas femeninas y en un 5 por 100 los casos de causa desconocida, aunque estas cifras también hay que tratarlas con reserva (Congreso de los Diputados, 1986: 51-54). Además de una demanda efectiva, lo que legitima una nueva tecnología es su utilidad, su rendimiento, su eficacia. En este terreno disponemos ahora, afortunadamente, de algunos datos contrastables. Edwards, el "padre" de la primera niña de probeta, durante una visita a Barcelona en octubre del año pasado declaraba a la prensa un 30,7 por 100 de éxitos ("embrión convertido en niño — sic-, llevado a la cuna") en la implantación de tres embriones en madres menores de cuarenta años (El País, 26 de octubre de 1985). El doctor Barri, por su parte, informaba a la Comisión Especial de Estudio de un rendimiento global del 20 por 100 de embarazos en transferencias de uno a tres embriones por ciclo en el Instituto Dexeus, señalando que este porcentaje era equiparable a la naturaleza humana, ya que "el hombre es, dentro del reino animal, la especie que tiene el fallo reproductivo más alto". Pero embarazos no son nacimientos. Efectivamente, como el doctor Barri aclaró más tarde, de este 20 por 100 de embarazos, de un 9 a un 10 por 100 acababan en aborto. Claro que nada le impide, en principio, a una mujer que ha tenido un fracaso en el primer ciclo el intentar una segunda, tercera o incluso más veces $^{14}$.

Pero hay también voces que denuncian lo engañoso de estas cifras. Como han mostrado Corea e Ince en un estudio de las tasas de "éxito" logradas por clínicas de FIV en Estados Unidos, el inflar estas tasas contabilizando transferencias de embriones o embarazos por laparoscopia en lugar de nacimientos vivos es una práctica común para estimar la eficacia de estos

\footnotetext{
${ }^{13}$ Esta cifra se refiere a parejas estériles entre veinte y treinta y cinco años aptas para el tratamiento de FIV; a finales de 1985 existian en España unos trece centros de FIV, principalmente privados; se ha propuesto que la Seguridad Social asumiese este servicio.

${ }^{14} \mathrm{Si}$ se descuenta el coste económico y psicológico; un ciclo de FIV en el Instituto Dexeus cuesta unas 300.000 pesetas y cada intento posterior unas 150.000 pesetas (Congreso de los Diputados, 1985a: 10906-10912).
} 
procedimientos. Françoise Laborie, que participó en noviembre del año pasado en la primera audición pública de la Comisión Jurídica y de Derechos Humanos del Parlamento Europeo sobre "Aspectos jurídicos y éticos de la ingeniería genética", realizado en Bruselas, igualmente cuestiona las tasas de "éxito" manejadas por la comunidad médica. En el caso de Francia, donde a fines de 1984 existían aproximadamente 60 centros de FIV, si se calcula el número de nacimientos logrados por número de mujeres que habían iniciado un tratamiento de esterilidad por FIV, teniendo en cuenta los fracasos en las diferentes etapas del procedimiento, los éxitos por ciclo no excedían el 7 por 100 en las mejores clínicas (Labourie, 1986; Corea e Ince, 1987) ${ }^{15}$.

El que las nTR constituyan una agresión a nuestra integridad como personas se debe, no obstante, a algo más que a la manipulación engañosa e interesada de la información sobre las implicaciones, la utilidad y la eficacia de estas técnicas motivada por el afán de gloria, de lucro y de poder de aquéllos que las impulsan. Subyacente a esta manipulación está el androcentrismo de la propia ciencia y tecnología modernas hechas en interés de los hombres $y$, por tanto, adversas a nuestras necesidades reales como personas. La sociedad de clases nos oprime y nos discrimina como mujeres no porque esté dominada por seres de sexo masculino, sino porque una sociedad clasista es inherentemente sexista.

Como Webster sugería recientemente, "la biología moderna y la medicina están inevitablemente relacionadas con cuestiones políticas" (1981: 1). Tanto la ciencia como la tecnología están inspiradas por el entorno sociopolítico en que se desarrollan y a su vez contribuyen a reforzar los valores y las relaciones de dominación que las engendran. Desde el siglo pasado presenciamos una convergencia real entre la ciencia y la tecnología. Este proceso ha producido una transferencia del poder de decisión de los supuestos beneficiarios de la ciencia a los científicos que, en connivencia con el complejo industrial en expansión, han utilizado su dominio para sus propios intereses y beneficios. Pero estos intereses no son el mero producto de ambiciones personales

\footnotetext{
${ }^{15}$ Informe presentado (Corea e Ince, 1987) en la Women's Emergency Conference on the New Reproductive Technologies realizada en Vaellinge (Suecia), del 3 al 8 de julio de 1985; Informe presentado (Labourie, 1986) en el Women's Hearing in Genetic Engineering and Reproductive Technologies, realizado en el Parlamento Europeo del 6 al 7 de marzo de 1986, organizado por GRAEL (organización del grupo Arco Iris del Parlamento Europeo) y FINRRAGE (Red Internacional Feminista de la Resistencia a la Tecnología Reproductiva).
} 
individuales, sino que se encuadran en los valores determinados por las relaciones de poder dominantes. No es promovido cualquier tipo de investigación. Así, mientras que el desarrollo de la tecnología genética ha sido posible por el generoso apoyo financiero, tanto privado como oficial, que ha recibido, tengo mis dudas de si una investigación antropológica, por ejemplo, sobre la ideología de la maternidad y sus implicaciones sociales, recibiría similar apoyo. Es igualmente sintomático que no se hayan desarrollado aún métodos de contracepción de uso masculino eficaces, mientras que se aplican tecnologías de punta a la procreación humana.

No estoy desechando el conocimiento basado en la investigación como tal. Nosotras mismas necesitamos el saber para poder detectar los peligros del creciente dominio técnico y de la medicalización de nuestras vidas y defendernos contra ellos. Pero una ciencia alternativa también requiere una alteración de las relaciones de poder. Como decía María Mies al plantearse la simple pregunta: “¿Por qué necesitamos todo esto?":
"Antes de que sea posible una utilización alternativa de la tecnología, tendrian que ser creadas primero condiciones alternativas. Es un hecho histórico que las innovaciones tecnológicas en el contexto de relaciones de dominación explotadoras sólo conducen a una intensificación de la explotación de los grupos oprimidos. Esto se aplica en particular a las nuevas tecnologías reproductivas, una tecnología para la producción industrial de seres humanos" (Mies, 1985: 6).

Los biólogos y los médicos nos dicen que no hacen más que responder a las necesidades y las demandas de la población, que no pretenden nada más que ayudar a parejas estériles a tener un hijo propio. Estos científicos y tecnólogos no se paran a pensar sobre el porqué de esta obsesión por tener un hijo propio en un mundo en que, por otra parte, se dice que ya nacen demasiados niños, muchos de los cuales mueren de malnutrición o de hambre. Pero ¿con qué fin real se han desarrollado las nTR, qué deseos satisfacen y a quién sirven realmente?

\section{RAZÓN SOCIOPOLITICA DE LAS NUEVAS TECNOLOGÍAS REPRODUCTIVAS}

El rápido avance de las $n T R$ ha despertado inquietud en muchos círculos. Pero lo que ha llamado la atención pública y lo que ha provocado preocupación entre políticos, juristas y moralistas no son las 
consecuencias que tienen estas técnicas para las mujeres, sino el que amenacen subvertir las nociones consagradas de paternidad, maternidad, filiación y herencia. Al ser posible ahora la fecundación con material reproductivo de donantes, surge un tercero, o más individuos, que participan en la procreación, lo cual pone en cuestión el vínculo genético individual como criterio acreditativo de la maternidad y de la paternidad. Así, al atentar contra ella, estas técnicas ponen en evidencia esta concepción esencialmente genética de la procreación. Cuando aún no era posible la congelación de semen, la IA seguramente se restringía, incluso por razones morales, sobre todo al ámbito conyugal. Al ser factible ahora también la transferencia de óvulos y embriones, se amplía aún más el círculo de individuos implicados en un acto de procreación. Es esta disolución del vínculo biológico individual entre padres e hijos lo que plantea problemas legales y morales. Pero hay que añadir en seguida que, aunque las nTR planteen contradicciones para las viejas nociones genéticas individualistas de maternidad y paternidad, son, no obstante, estas mismas nociones las que inspiran las nTR al prometer "aliviar la esterilidad" mediante la producción de un hijo propio para la pareja estéril.

Si las nTR están de alguna manera inspiradas por estos valores reproductivos hay que interrogarse entonces sobre sus raíces y el papel que ellos han jugado en el contexto de los cambios que han ocurrido en el comportamiento reproductivo en el último siglo.

La constitución de la sociedad de clases en el siglo pasado engendró una ética individualista liberal, reflejada también en una noción individualista posesiva de la maternidad y de la paternidad. Sin embargo, contradiciendo esta ética liberal competitiva que concibe a la persona como dueña de su propio destino, se consolidó al mismo tiempo una concepción genética, naturalista, de la reproducción, según la cual la identidad social de los individuos es determinada en última instancia por su origen biológico. Es decir, por una parte, el individuo es libre de forjar su propio destino y, por tanto, es responsable por él, pero por otra, esta libertad individual queda circunscrita por el origen genético, es decir por la condición social entendida muchas veces como "natural" de sus progenitores. Esta "naturalización" de la identidad social en la sociedad de clases queda patente en corrientes de pensamiento tales como el darwinismo social, las doctrinas eugenésicas y el racismo. Todas ellas tienen en común el atribuir la desigualdad social a deficiencias de base 
genética y el pretender proteger la "raza", es decir la jerarquía social y la preeminencia política y social de las élites dentro de ella, o el mejorar la especie, mediante el control de la reproducción. Un elemento central de esta naturalización de la reproducción social es una obsesión por la paternidad biológica (Stolcke, 1982).

Se podría alegar que en países como Francia y España, cuyo derecho familiar deriva del Código napoleónico, según el cual el padre es el marido de la madre, la paternidad se basa en un vínculo social y no natural. Pero hay que recordar que el mismo derecho le concedía al marido, mediante instrumentos legales tales como la penalización del adulterio, el monopolio sobre la sexualidad de la esposa. Y además, en estos países la paternidad siempre ha sido entendida popularmente como vínculo de "sangre". Aunque el adulterio ha sido suprimido de la nueva legislación familiar española, en lo que se refiere a la acreditación de la maternidad y de la paternidad se han introducido algunos criterios más estrictamente biológicos. La ley de 13 de mayo de 1981 concede la igualdad de derechos y obligaciones a la madre y al padre, e igualdad de derechos de los hijos (fuesen o no de matrimonio), pero permite también la investigación de la paternidad mediante pruebas incluso biológicas sustituyendo el concepto de que "el padre es el que demuestra las nupcias o matrimonio", por el de "el padre es el que demuestra la sangre" estableciendo con ello la llamada "verdad biológica". Si de esta manera la legislación les ha dado a las mujeres un instrumento para exigir responsabilidades al genitor del hijo, al mismo tiempo ésta consolida una concepción biológica individual de la paternidad (Congreso de los Diputados, 1985a; 1986: 33-49) ${ }^{16}$.

Esta consagración de la paternidad biológica históricamente tuvo graves consecuencias para las mujeres. Los burgueses necesitaban controlar la capacidad procreadora de sus mujeres para garantizar su acceso exclusivo al útero escogido. La sexualidad tenía como fin único la procreación dentro del matrimonio; la maternidad era concebida como función primordial de las mujeres y la herencia era entendida a la vez como transmisión de patrimonio y de la identidad genética. Al naturalizar las desigualdades sociales ocurre lo mismo con las diferencias sexuales y la reproducción social.

\footnotetext{
${ }^{16}$ Los juristas que participaron de la Comisión Especial de Estudio precisamente apuntaban los efectos de las nTR para las concepciones tradicionales de la paternidad y de la maternidad y de la familia.
} 
Las nTR parecen romper esta maraña ideológica en la medida en que separan la sexualidad de la procreación y en cierto modo desvinculan la paternidad/maternidad de una relación biológica. Así, estos avances parecen prometernos a las mujeres que "la biología ya no ha de ser nuestro destino". Sin embargo, quiero subrayar en seguida que la biología como tal nunca ha sido nuestro destino como mujeres. El significado de nuestra biología y las limitaciones que ella aparentemente nos ha impuesto siempre han sido el producto de la construcción social de hechos biológicos. Uno de los temas preferidos de los/las antropólogos ha sido el estudio de sistemas de reproducción social y de parentesco. Una de las aportaciones que hemos hecho ha sido demostrar que los sistemas y las conceptualizaciones de la procreación son siempre construcciones sociales que varían histórica y culturalmente. Así, por ejemplo, la teoría de la concepción de los trobiandeses, una sociedad matrilineal del Pacífico occidental, le atribuye a la madre el papel esencial en la formación del feto, mientras que el genitor es concebido como marginal a la concepción y el papel de padre social lo asume el hermano de la genitora madre. En cambio, la teoría de la concepción reflejada en la mitología griega (por ejemplo, en la Orestíada) concibe a la genitora como mero vehículo de la "esencia" que el feto deriva exclusivamente del genitor = padre. Así, Palas Atenea había sido parida de la cabeza de Zeus.

En la cultura occidental el feto es concebido como el producto combinado de la masa genética de ambos genitores. Esta concepción cultural queda reflejada en el marco jurídico que regula nuestro sistema de filiación que, en contraste con los dos casos arriba citados, es cognaticio o bilateral. De hecho, ni la conceptualización de la procreación ni las convenciones jurídicas que la expresan son hechos puramente biológicos, sino que tienen raíces sociales.

Algunos antropólogos han intentado minimizar las dificultades conceptuales y jurídicas que plantean las nTR al subvertir nuestras nociones tradicionales de paternidad y maternidad apuntando las teorías de la concepción culturalmente muy diversas vigentes en otras sociedades (Héritier-Augé, 1985a y 1985b; Rivière, 1985). Sin embargo, una postura relativista de este tipo tiene un valor explicativo limitado en la medida en que no se plantean ni las condiciones de desarrollo ni las finalidades de estas teorías. Los principios que regulan la filiación en cualquier sociedad están estrechamente vinculados a sus principios estructurales al definir parcial o totalmente la identidad social de sus 
miembros. Por tanto, ni el desarrollo de las nTR ni las reacciones de diferentes sectores sociales frente a ellas pueden ser comprendidos sin tener en cuenta este contexto socioestructural.

\section{Selección DE "APTOS", PERO EliminaCión de "NO APTOS"}

Las técnicas reproductivas y la medicalización de la procreación datan ya de hace casi dos siglos. Linda Gordon estudió las luchas de las mujeres por el control de nacimientos y la autodeterminación reproductiva en Estados Unidos desde finales del siglo pasado. Lo que estaba inicialmente en cuestión era la libertad de las mujeres de limitar la procreación. En un primer momento, en Estados Unidos, en el contexto de rápidos cambios sociodemográficos, los sectores conservadores se oponían firmemente a las demandas feministas de libertad reproductiva y maternidad voluntaria. La derecha temía el descenso de la tasa de natalidad en la clase dominante, que a sus ojos parecía amenazar la supremacía "racial" y los privilegios de clase de las élites, así como los nuevos espacios de libertad que la contracepción ofrecía a las mujeres. En un segundo momento, sin embargo, ante la difusión de prácticas contraceptivas, estos mismos sectores se mostraron más receptivos al control de nacimientos sin abandonar, en cambio, sus posturas eugenésicas. Como alegaban, si la elite tenía menos hijos se trataba de controlar también la tasa de fecundidad de la masa creciente de pobres. Es también en este período - los años treinta- cuando aumentan las inseminaciones artificiales. Pero, como señala Gordon, este cambio de actitud ante la contracepción no significó una auténtica libertad reproductiva para las mujeres:

"Aun en un país donde los contraceptivos son tan ampliamente utilizados como en Estados Unidos no se ha logrado la autodeterminación reproductiva para las mujeres...; esto es así porque la libertad reproductiva no puede ser aislada de otras libertades humanas. Los patrones reproductivos son siempre determinados por la moral sexual vigente, la condición general de las mujeres, la formación de clase y la naturaleza de la lucha por el cambio social" (Gordon, 1976: 404).

El panorama reproductivo general de posguerra resulta muy paradójico. Al aumento de la tasa de natalidad en la inmediata posguerra, en los países industrializados, siguió un marcado descenso acompañado de una oferta y difusión creciente de contraceptivos predominantemente de uso femenino. Hacia la segunda mitad de los años setenta, la tasa de 
crecimiento de la población en algunos países europeos, como Alemania y Francia, había bajado a cero. Un descenso aún más rápido se ha producido en España en los últimos diez años. La tasa actual de fecundidad es de 1,7 hijos de media por mujer, muy por debajo del valor de reemplazo de las generaciones, que se sitúa en torno a 2,1 hijos por mujer.

Este descenso en la reproducción "nacional" ha despertado alarma tanto en Europa como en el Estado español. El progresivo envejecimiento de la población por la disminución del contingente de jóvenes y el aumento de la esperanza de vida acarrearía graves problemas económicos al disminuir la población activa en proporción a la no activa. Por esto en Francia un anuncio reciente llamaba a las francesas a tener más hijos: “¡Francia necesita niños...! La vida no es sólo sexo" (II n'y a pas que le sexe dans la vie). Aquí, en España, un país que padece de una tasa de desempleo de un 22 por 100, y además con una tasa comparativamente baja de población activa, se ha desatado una verdadera ofensiva natalista ${ }^{17}$.

Mientras que en los países europeos crecía la angustia natalista en los años sesenta y setenta, el Gobierno de Estados Unidos adoptaba una política agresivamente controlista para el Tercer mundo financiando directa o indirectamente amplios programas de control de la población. El argumento era que el subdesarrollo, la miseria y el hambre en el Tercer mundo se debían sobre todo a las altas tasas de natalidad que desviaban recursos escasos de urgentes proyectos de desarrollo. De hecho, sin embargo, subyacía a esta política centralista la opción por reducir el número de pobres en lugar de compartir la riqueza de los ricos con ellos ${ }^{18}$.

También en los años setenta, y otra vez en Estados Unidos, gana rápida popularidad un nuevo discurso científico, la sociobiología, que surge como uno de los soportes ideológicos del nuevo liberalismo económico. Nótese que la sociobiología no es una pequeña moda académica. Las

\footnotetext{
${ }^{17}$ El presidente Pujol insiste en que "hay que ir por el tercer hijo", aunque en realidad debería llamar a un aumento de nacimientos de niñas si teme que los catalanes se estén acabando. Pero la preocupación es igualmente intensa en el Gobierno central (Catalán Deus, 1986). Políticos y economistas publican largas materias en la prensa sobre la catástrofe demográfico-cultural y económica que se avecina (Lesourne, 1986 y Leal, 1986).

${ }^{18}$ El presidente Reagan adoptó recientemente una política antiintervencionista neoliberal en materia de población, pero es también sabido que entidades privadas estadounidenses continúan sufragando generosamente el control de población en los países del Tercer mundo.
} 
obras más destacadas fueron publicadas con enorme publicidad por las editoriales de universidades de élite, Harvard y Oxford, y además traducidas con sorprendente rapidez aquí, en el Estado español. Según la sociobiología, todo comportamiento social tiene una base genética y todas las instituciones sociales tienen una sola función, a saber, la maximización genética individual. En lo que se refiere a las mujeres, estaríamos genéticamente programadas para relaciones monogámicas heterosexuales y la maternidad, en cuanto que para los hombres la estrategia más eficaz de maximización genética sería el fecundar el mayor número de hembras posible. La sociobiología refuerza así una ideología de la maternidad en un momento en que en Occidente aparentemente la familia tradicional, compuesta por un hombre que la sustenta y su mujer, que se dedica al trabajo doméstico y al cuidado de los hijos, está en disolución, y en que un número creciente de mujeres se incorporan al mercado de trabajo, la natalidad va en descenso y el movimiento feminista parece amenazar la supremacía masculina. Las connotaciones eugenésicas y sexistas de esta nueva doctrina son evidentes ${ }^{19}$.

Por un lado, los estados industrializados promueven la reducción de las poblaciones del Tercer inundo; pero, por otro, profesan muchas veces una política natalista doméstica acompañada de un discurso "científico" que recupera la familia tradicional y la ideología de la maternidad, que a su vez implícitamente afianza la paternidad. La forma de combatir la amenaza natalista del Tercer mundo y de reducir las cargas sociales por el descenso de la natalidad en el primero sería reincorporar a las mujeres al hogar para que reproduzcan los productores y los herederos legítimos de patrimonio del futuro y cuiden de ellos.

Pero ¿qué tiene que ver todo esto con las nuevas tecnologías reproductivas? Aparentemente, poco; pero en realidad, mucho. Como declaraba recientemente Hernández Gil, subsecretario del Ministerio de

\footnotetext{
${ }^{19}$ Judith Shapiro (1986) en su crítica a Symons (1980), discípulo del padre de la sociobiología, Edward O. Wilson, señala las implicaciones sexistas de esta doctrina: "Symons lo ha entendido al revés. En vez de ver la quintaesencia de la odisea masculina como el intento de difundir lo más ampliamente sus genes, podriamos verla también como una lucha por la paternidad, por transformar lo que podría ser una inversión física mínima en una ventaja social máxima... Desde esta perspectiva, el matrimonio puede ser considerado menos como una forma que tienen las mujeres de tener ayuda para cuidar de los hijos - después de todo, otros muchos pueden asumir esta función- que una manera para que los hombres no sean meros genitores, sino padres"
} 
Sanidad y Consumo, en relación con el descenso de la natalidad y sobre los centros de planificación familiar:

"No son centros de planificación, sino de orientación familiar, centros que ayuden a tener libremente los hijos que se deseen, con el espaciamiento que se quiera, y que además luchen contra la esterilidad que sufren unas 300.000 parejas españolas. Estoy seguro de que en este campo, con la ayuda de los medios con que se cuenta, se pueden conseguir muchos niños nuevos para quienes los desean y no han podido hasta ahora tenerlos" (Catalán Deus, 1986: 40).

Detrás de estas campañas natalistas se esconden en realidad posturas ideológicas eugenésico-racistas más que problemas económicos insuperables. La forma más eficaz y al mismo tiempo más humana de repartir mejor los gastos sociales actuales seria, efectivamente, darles trabajo a los aproximadamente tres millones de parados de este país. Y en la eventualidad, por cierto bastante remota considerando el paro tecnológico, de que por el efecto conjunto del descenso de la natalidad y de una recuperación económica, se dé una situación de pleno empleo, siempre queda la posibilidad de abrir las fronteras a los desamparados del Tercer mundo. Sin embargo, como el político francés Michel Debré ya advertía en 1979, el problema de la natalidad es sobre todo político. Si las francesas no aceptasen su deber patriótico de producir más niños, eso conduciría a una situación de:

"Productores sin mercado, jubilaciones que el estado ya no será capaz de pagar, legislación social totalmente puesta en cuestión, peligroso aislamiento de europeos envejecidos en un mundo superpoblado en el cual el Tercer mundo juega la carta de la natalidad" (Debré, 1979) ${ }^{20}$.

Incluso aquellos que prevén la inmigración como fuente de mano de obra del futuro para Europa advierten con insistencia de los peligros para su propia identidad "cultural" y cohesión social, de la llegada de amplios contingentes de población no europea. Se dice también que una

\footnotetext{
${ }^{20}$ Sin embargo, posturas natalistas con sus consecuencias sociopolíticas no son un privilegio de las sociedades capitalistas. Al igual que en los países europeos occidentales, en las sociedades socialistas realmente existentes se vislumbran las posibilidades natalistas que las nTR parecen ofrecer. Así, Vera D. Rosanova sugeria en su informe sobre Artificial insemination: the views of Soviet women and physicians, manuscrito inédito: "Es necesario pesar con cuidado todas las oportunidades positivas que ofrecen los métodos de inseminación artificial que parecen prometer un aumento de la tasa de natalidad y un refuerzo de la familia" (Rosanova, s/f: 4).
} 
población envejecida es menos receptiva al cambio, menos creativa, pero no se pone en cuestión nuestra propia noción cultural de vejez ni se plantea la posibilidad de emplear "viejos" en actividades productivas (Lesourne, 1986).

Es irrealista suponer que las nTR puedan contrarrestar de forma significativa el descenso de la natalidad. Puede además parecer paradójico que los políticos y economistas lamenten la baja fecundidad en Europa, que parecería indicar un debilitamiento del "instinto materno" por parte de las mujeres europeas, mientras que los defensores de las nTR justifican éstas con el deseo y el derecho de las mujeres a tener un hijo propio, lo cual supondría más bien que este "instinto" continúa intacto. Pero el descenso en la natalidad parece deberse sobre todo a la reducción en el número de hijos deseados a la "parejita" proverbial y a la mayor eficacia en evitar hijos no deseados ${ }^{21}$. El deseo por un hijo, en cambio, permanece inalterado.

Subyace, a las angustias natalistas en el Primer mundo y a la promoción de las $n T R$ como procedimientos para darles un hijo propio a padres y/o madres infértiles, la misma ideología en el fondo eugenésico-racista y sexista de la procreación. Ambas están contaminadas por una doctrina que atribuye la desigualdad entre clases y entre pueblos a deficiencias naturales, es decir, genético-raciales. Desde esta perspectiva, se trata de preservar la preeminencia del Primer mundo asegurando la reproducción genética de sus habitantes. Y este afán reproductivo redunda también en la manipulación de la capacidad procreativa de las mujeres ${ }^{22}$.

${ }^{21}$ Gérard Calot, "La Baisse de la fécondité en France: Reactions qu'elle a suscitées dans les divers milieux politiques", conferencia presentada en el Centre d'Estudis Demográfics de la Universidad Autónoma de Barcelona el 18 de abril de 1986. Calot es director del Institut National d'Études Démographiques de Francia y parece compartir los temores expresados, por ejemplo, por Jacques Lesourne (1986).

${ }^{22}$ Peter Singer, profesor en el Centro de Bioética de la Monash University de Victoria (Australia), resaltaba recientemente los beneficios eugenésicos de las nTR en los términos siguientes: "Si consiguiésemos operar sobre la inteligencia, ¿deberiamos limitarnos solamente a eliminar los casos de deficiencia mental, o bien deberiamos intentar elevar también el coeficiente medio? Si pudiésemos eliminar las personalidades demasiado propensas a las depresiones, ¿sería un error tratar de dar vida a personas un poco más alegres de lo que solemos ser la mayoría de nosotros? Si eliminásemos las tendencias hacia la violencia criminal, ¿no sería posible desarrollar un poco la amabilidad en el ánimo humano? En definitiva, si los riesgos de semejante empresa son altos, lo son también sus beneficios. Queda por demostrar, claro, que la inteligencia, la depresión y la criminalidad tienen una base genetica" (Singer, 1986: 14-15). 
A primera vista, no obstante, los últimos logros de las nTR, la fecundación con semen, óvulos o embriones donados, parecerían apuntar a una superación de las viejas concepciones biológico-genéticas de la paternidad y de la maternidad.

La contracepción había roto la relación necesaria entre el acto sexual y la concepción. Gracias a ella, la sexualidad dejó de tener como única finalidad y consecuencia la procreación. La fecundación artificial, o "fecundación asistida", como los expertos prefieren llamarla ahora (Congreso de los Diputados, 1986; AA. VV., 1985) ${ }^{23}$, permite además separar la paternidad / maternidad biológicas de la paternidad / maternidad sociales ${ }^{24}$.

Por eso, la fecundación por donantes ha generado preocupación. Como argumentaban algunos participantes en las sesiones celebradas por el Grupo de Trabajo constituido en la Dirección General de los Registros y del Notariado, para analizar los problemas civiles que plantean la IA y la FIV:

"Desde el punto de vista de los principios, la inseminación heteróloga dentro del matrimonio tiene aspectos inquietantes...; esta operación perturbará gravemente la vida conyugal, con la consiguiente repercusión en el hijo mismo. La deficiencia viril del marido, en orden a la fecundidad, es suplida por un extraño. Son las células sexuales de este otro varón las que provocarán la metamorfosis que para la mujer implica el embarazo. Los ciclos vitales, la vida biológica y afectiva de la

\footnotetext{
${ }^{23}$ Este cambio terminológico no es fortuito. Por una parte quiere eliminarse la connotación "antinatural" de estas técnicas para paliar la oposición de sectores de derecha, pero también quiere subrayarse el carácter asistencial curativo de ellas ante las críticas por parte de aquellas que denuncian su manipulación.

${ }^{24}$ Así, en el Informe de la Comisión Especial de Estudio se maneja la siguiente tipología: a) Maternidad natural en el sentido tradicional. b) Maternidad biológica que puede ser plena cuando la mujer aporta el óvulo y ella misma madura el embrión resultante de la FIV en su útero, y no plena cuando el óvulo o el embrión es transferido a otra mujer. c) Maternidad educacional o afectiva que puede darse en el caso de maternidad biológica plena, no plena y por adopción. d) Maternidad de deseo por la que una mujer pone de manifiesto su deseo de relación maternofilial y que puede realizarse en todos los casos anteriores. e) Maternidad legal o la de la madre aceptada por las leyes como tal.

En el caso de la paternidad se dan las mismas posibilidades salvo la distinción entre vinculo genético y por gestación propio de la mujer. A este respecto, la Comisión entendió que la maternidad de gestación es más importante que la maternidad genética y que la maternidad educacional tiene un alto rango. Así, en lo que se refiere a la maternidad, la Comisión se mueve de forma ambivalente entre criterios biológicos y sociales en el intento de establecer criterios para una reordenación jurídica de la maternidad y de la paternidad a la luz de las nTR (Congreso de los Diputados, 1985a: 37-42).
} 
mujer sufrirán un cambio profundo, y un cambio, no por la fuerza sexual de su marido, sino por la fuerza sexual de un extraño. En la gestación, en el parto, en la lactancia, en el nuevo nacido y en su respectivo poder genésico estará siempre presente el otro. La vivencia de estos fenómenos no puede por menos de constituir una grave perturbación en la vida íntima de la pareja. Con la consiguiente repercusión en el hijo, que lo que necesita, para el correcto desarrollo de su personalidad, es un hogar con un mínimo de unidad afectiva en los estratos profundos de las personalidades que lo integran" (Ministerio de Justicia, 1986: 11$)^{25}$.

Esta postura biologicista extrema, que confunde sexo y afecto con genética, seguramente no es compartida por la profesión jurídica en general, pero no deja de ser sintomática de los valores reproductivos vigentes.

No obstante, las comisiones de estudio de estas nuevas técnicas, tanto extranjeras como aquélla creada por la Cámara de Diputados del Estado español, han hecho recomendaciones para el caso de donación de semen, óvulos o embriones que tienen innegables connotaciones eugenésicoracistas. En todos los casos se proponen procedimientos de selección del material reproductivo no sólo para prevenir la transmisión de enfermedades genéticas, sino para asegurar la mayor "similitud fenotípica" con el padre y la madre por parte de donantes (Congreso de los Diputados, 1985b: 10212).

En el Informe Warnock, de Inglaterra, utilizado extensamente por la Comisión Especial de Estudio del Congreso, se rechazaba, la práctica de algunas clínicas estadounidenses de ofrecer descripciones detalladas de los donantes para permitirles a las parejas que escojan a éstos, pero asimismo se recomendaba que la pareja recibiese, "para su propia tranquilidad", suficiente información relevante sobre el donante: "Ésta debería incluir algunos datos básicos sobre el donante, tales como su

\footnotetext{
${ }^{25}$ La abogada Carmen Frías García, por ejemplo, estaba en total desacuerdo con este planteamiento. Cabe notar también la utilización del término "heterólogo" que los propios biólogos rechazan para los procedimientos en cuestión en la medida que se refiere a la fecundación entre diferentes especies. En la IA el donante obviamente pertenece a la especie humana. Cabe notar aquí también la recomendación que en una clínica de FIV española se suele hacer a la pareja de intensificar las relaciones sexuales después de una fecundación artificial con semen de donante para ayudarle al marido a superar su sentimiento de exclusión.
} 
grupo étnico y su salud genética" (Warnock, 1985: 24) ${ }^{26}$. La Comisión Warnock no define lo que entiende por "grupo étnico", si el criterio sería religioso, cultural, racial...

La práctica y las recomendaciones para la fecundación por donantes en España es semejante. Así, el doctor Calaf Alsina, del Hospital de San Pau de Barcelona, informaba a la Comisión Especial de Estudio en relación a "normas de control de calidad" del material reproductivo donado:

"Nosotros queríamos dar como garantía el hecho de que, como ocurre en la mayoría de bancos, bien sea de una forma manual o informatizada, se asegure que una pareja que, por ejemplo, tiene un determinado tipo de cabello rubio y lacio y ojos azules no vaya a tener un hijo con pelo negro y rizado y piel morena, cuando fenotípicamente no parecería posible" (Congreso de los Diputados, 1985a: 10217) ${ }^{27}$.

Sorprende un tanto este ejemplo teniendo en cuenta que en el fenotipo de la península ibérica no predominan precisamente el cabello rubio y los ojos azules.

El informe de la Comisión Especial de Estudio, por su parte, recoge dos recomendaciones para la selección de donantes, aparte de sugerir el

${ }^{26}$ El informe preparado por la Comisión Benda del Parlamento de la República Federal de Alemania sobre fecundación in vitro y terapia genética, por obvias razones históricas, es bastante más cuidadoso en relación con la selección de donantes. Aunque "cuando prevalece una actitud adecuada por parte de la pareja es preferible la inseminación heteróloga a una adopción, ya que el niño engendrado por la esposa recibirá la mitad de sus aptitudes hereditarias de ella, y ya que el marido puede reconocer en el niño una 'parte' de su cónyuge", no recomienda este procedimiento por el efecto que puede tener para el desarrollo espiritual y psíquico de éste. Además, la inseminación heteróloga plantea la difícil cuestión de la selección del donante: "La selección del donante por el médico implica el peligro que entren en juego aquí criterios de la eugenesia y de la cría de seres humanos supuestamente valiosos". Sin embargo, como se añade, "la salud física y psíquica del donante de semen debería determinar la selección". Me pregunto si la salud psíquica tiene base genética (Bundesrepublik Deutschland, 1985: 21-23).

${ }^{27} \mathrm{O}$ como sugiere el doctor Lacadena como genetista sobre la conveniencia de mantener el secreto sobre el origen del semen o del óvulo y sobre la selección de donante: "Si se quiere mantener el secreto del origen en la fecundación in vitro de una persona, no se puede utilizar el semen de una persona de raza negra cuando se trata de una pareja de raza blanca, porque entonces habría una incongruencia genética entre el producto biológico, el nuevo ser, con el origen de sus padres" (Congreso de los Diputados, 1985a: 10645-10646). Cabría preguntar aquí sobre el porqué del interés en mantener el secreto sobre el origen. Si la cuestión es evitar que el niño nacido de fecundación por donante exija responsabilidades de éste, sería perfectamente posible suprimir tales responsabilidades legalmente sin recurrir a la selección de donantes por fenotipo o raza. De hecho, la Comisión Especial de Estudio recomienda esto, sin suprimir, en cambio, criterios de selección de donantes de este tipo (Congreso de los Diputados, 1985a: 89). 
anonimato de éstos. Por un lado, "se deberá garantizar que los donantes tengan la mayor similitud fenotipica e inmunológica y las máximas posibilidades de compatibilidad con la mujer receptora y con el varón de pareja o matrimonio que constituyan", y por otro, "las receptoras de gametos o embriones y el varón... tienen derecho a conocer determinadas características del o de los donantes, tales como el fenotipo, el grupo étnico, el grupo sanguíneo, la salud genética, etc.; pero no su identidad" (Congreso de los Diputados, 1985a: 164) ${ }^{28}$. En el glosario anexo se define "fenotipo" como: "Los rasgos externos o morfológicos manifestados por un individuo, por ejemplo, los ojos azules, la forma del cráneo". No se da, sin embargo, el significado de "grupo étnico" (Congreso de los Diputados, 1985a: 181).

Las posibilidades eugenésicas que estas recomendaciones permiten son evidentes. Si, como parece ser, es el blanco con ojos azules el fenotipo que se valoriza, no es exagerado suponer que parejas morenas puedan incluso escoger donantes con estas características fenotípicas "para mejorar la raza", como antaño se solía decir. Pero una regulación de la selección de donantes en estos términos puede plantear otro problema. Una normativa selectiva de la donación de semen, óvulos y embriones puede, en efecto, resultar anticonstitucional en el caso de que se creen bancos públicos en mayor número, ya que la Constitución establece que:

"Todos los españoles son iguales ante la ley, sin que pueda prevalecer discriminación alguna por razón de nacimiento, raza, sexo, religión o cualquier otra condición o circunstancia personal [art. 14]".

En el caso de la fecundación por donantes, la paternidad y/o maternidad, según el caso, efectivamente no se basan en un vínculo genético. Pero mediante la selección de los donantes se introducen mecanismos que en el fondo persiguen el mismo fin, a saber, no sólo el que los hijos sean simplemente genéticamente sanos, sino que además posean la identidad fenotípica de los padres. Es bien posible que los médicos y los técnicos no siempre compartan estos ideales eugenésicos, pero evidentemente responden a los deseos raciales de sus clientes, motivados por prejuicios raciales latentes y por valores sexuales vigentes. Si un niño nacido de inseminación artificial con semen de donante resulta fenotípicamente muy diferente del marido, éste teme además que pueda delatarlo por no

\footnotetext{
${ }^{28}$ Se sugiere confiar la selección a los criterios del equipo médico que realiza la fecundación. 
haberlo fecundado él ${ }^{29}$. Este temor proviene de la noción biológica de la procreación junto con la norma de fidelidad sexual conyugal.

Parejas estériles individuales que buscan tener un hijo mediante fecundación, con semen $u$ óvulo de donante, porque no han podido encontrar un niño para adoptar localmente, puede que no tengan prejuicios con respecto al fenotipo del donante o la donante. Pero habría que ver también hasta qué punto realmente se plantea una adopción. Además, el que comisiones parlamentarias recomienden criterios raciales que permiten la selección fenotípica o étnica demuestra claramente, aunque hay quien quiera negarlo, las connotaciones y posibilidades eugenésicas de las $\mathrm{nTR}^{30}$.

Brasil ofrece tal vez el ejemplo más notable de las motivaciones racistas que subyacen en las nTR. Se trata del único país por ahora, junto con la India, donde convergen políticas agresivas de control de población generalmente financiadas por entidades extranjeras y aplicadas a mujeres pobres, con la práctica de la FIVTE en mujeres que pueden pagarlas. En este país, donde anualmente mueren miles de niños como consecuencia de la malnutrición y el hambre, por cierto, no se puede decir que falten candidatos para la adopción, sólo que, claro, éstos suelen carecer del fenotipo apropiado (Gomez dos Reis, 1985) ${ }^{31}$.

\section{4. ¿UNA NUEVA OPCIÓN REPRODUCTIVA O UNA FORMA DE OPRESIÓN?}

Quienes sufren las nTR en sus personas somos nosotras las mujeres. Nosotras servimos de conejas de Indias para la experimentación y la investigación que han producido estas nuevas técnicas reproductivas; son las mujeres las que son sometidas a procedimientos médicos, cuyas

\footnotetext{
${ }^{29}$ Así, el diario Ya del 22 de noviembre de 1985 informaba que el marido estéril de una pareja que buscaba una inseminación artificial con semen de donante le había rogado al médico: "Doctor, por favor, búsqueme un donante que sea blanco, porque si aparezco en Guadalajara con un mulato, el cachondeo se va a escuchar hasta en Zaragoza".

${ }^{30}$ Thibault propone "qu'on bannisse d'une fois pour toutes le spectre de l'eugénisme (...). Nous trainons là une séquelle du nazisme, et pour le public le mot eugénisme évoque des pratiques qui nont rien à voir (il faut le dire bien haut) avec le but des recherches actuelles: la prévention des handicaps à la naissance" (1985: 539).

${ }^{31}$ También en Brasil hubo varios casos en los últimos años de alemanes que ilegalmente intentaron adoptar niños brasileños del sur del país, una región de colonización predominantemente alemana, cuyo fenotipo era así similar. Ver también la noticia reciente sobre esterilizaciones de mujeres pobres patrocinadas por las autoridades de Brasilia en convenio con un llamado Centro de Investigación y Asistencia a la Mujer vinculado a organismos estadounidenses (EI País, 16 de junio de 1986).
} 
implicaciones no controlan, al servicio de una ideología clasista, sexista y, por tanto, racista que refuerza el papel históricamente subordinado de las mujeres, como reproductoras, para los productores.

Sin embargo, el argumento con el cual los "expertos", fascinados por las posibilidades que las nTR ofrecen para controlar el proceso de creación de la vida, refutan nuestra oposición a ellas suele ser el que las mujeres las quieren. Efectivamente, no se puede negar que exista una demanda real no sólo por parte de padres, sino también de madres potenciales, de estas técnicas.

Pero hay que preguntarse si, en la sociedad en que vivimos, este deseo por tener un hijo propio es verdaderamente libre.

Hay que tomar muy en serio el sentimiento de carencia y el sufrimiento real que puede producir la esterilidad en mujeres, y también en hombres, en una sociedad en que la maternidad biológica es concebida como facultad constitutiva fundamental de la identidad femenina y en que suele confundirse esterilidad masculina con falta de virilidad. Pero es necesario también distinguir entre una demanda socialmente inducida y un deseo libremente expresado.

Poco se sabe sobre las motivaciones personales de aquellas mujeres que se someten a un programa de FIVTE. Christine Crowe ha estudiado un grupo de mujeres que participaron en un programa de este tipo en el Royal Shore Hospital de Sydney, en Australia. Estas mujeres concebian la maternidad como parte integral del matrimonio. Ellas pensaban además que las mujeres, por ser mujeres, poseen cualidades inherentes específicamente femeninas tales como la afectividad, una actitud maternal y protectora, y entendían a la familia como constituida por una pareja y los hijos de ésta. Su propia esterilidad les había hecho dudar, no obstante, si la maternidad realmente era un elemento esencial de la femineidad, aunque, en última instancia, había prevalecido en ellas el deseo emocional de ser madres, Pero para estas mujeres la prioridad no era tanto el poder transmitir sus propios rasgos genéticos, a través de una maternidad biológica, sino que querían vivir sobre todo la experiencia social de la maternidad, Algunas habían intentado la adopción de un niño, que en Australia implica una larga espera. En cambio, todas aquéllas que no hablan acudido a una agencia de adopción habían dejado de explorar esta posibilidad, no por propia aversión, sino porque el marido prefería no tener hijos antes que adoptar un niño "de otro". Por tanto, parecían ser 
los hombres, más que las mujeres, los que concebían la paternidad en términos puramente biológicos. Pero, en cambio, son las mujeres las que sufren la principal presión social para tener hijos, las que históricamente han sido culpabilizadas por la esterilidad y las que tienen que someterse a una fecundación artificial.

Las finalidades de la FIV, de hecho, no resultan ser muy diferentes de aquéllas de las primeras IA. Tanto en un caso como en el otro se trata, en definitiva, sobre todo, de darle al marido un hijo de su propia "sangre". Se dejan de explorar así, además, las posibilidades de una concepción social y no individualizada de la maternidad y de buscar fuentes de gratificación emocional y de realización personal alternativas para mujeres estériles. Como concluye Christine Crowe:

"Mientras que para las feministas el derecho a elegir ha sido un principio primordial, una "elección" está siempre mediada por circunstancias sociales. En un mundo en que mujeres son culpabilizadas y estigmatizadas por su esterilidad, y en que la maternidad presupone una relación biológica, hay que preguntarse qué "opción" tienen realmente las mujeres estériles" (1985: 62) ${ }^{32}$.

Además, al ofrecer la posibilidad de tener un hijo vinculado biológicamente con los padres legales, al menos de forma parcial, las nTR refuerzan la noción individualizada de la maternidad y de la paternidad. Sin embargo, no hay que olvidar tampoco que las tasas de éxito obtenidas con la FIVTE son bajas. En el mejor de los casos, si aceptamos los porcentajes de "rendimiento" que divulga la profesión médica, sólo una de cada cinco mujeres que participan en un programa FIVTE logra finalmente producir un hijo. Para la mayoría que fracasa, en cambio, las

\footnotetext{
${ }^{32}$ Hay una necesidad urgente de replantear la concepción de la maternidad mediante más estudios con mujeres estériles y su actitud ante las nTR. Las feministas hemos tenido muchas veces actitudes ambivalentes ante la maternidad. En los años sesenta se tendía a confundir emancipación con liberación de la maternidad en lugar de analizar las condiciones sociales que hacen que ésta constituya una carga. Parece ser que más recientemente esta actitud ha cambiado algo tal vez porque ha llegado el momento de la decisión para las feministas de la primera hora. Pero una celebración de la maternidad en si me parece no menos problemática en la medida en que implica una postura igualmente naturalista. Algunas feministas se oponen a las nTR por ver en ellas la expropiación definitiva de las mujeres de nuestra facultad de crear vida considerada como la fuente principal de nuestro poder. Pero hay que tener en cuenta que esta facultad ha sido socialmente construida como elemento constitutivo principal de nuestra identidad excluyendo cualquier otra posibilidad de realización personal. Como subraya Renate Duelli Klein (1986), lo que está en juego realmente en el avance de las nTR es nuestra "autonomía e integridad física" como personas.
} 
nTR agravan el drama de su esterilidad. El pretender "normalizar" esta tasa de éxito comparándola con aquélla obtenida por el proceso natural de concepción es de un cinismo androcéntrico extraordinario. Se menosprecia el sufrimiento psíquico y físico y la manipulación que el someterse a una FIVTE significa para una mujer, para no hablar del placer, nada despreciable, que puede dar el "proceso natural", para no mencionar ya que éste además no va dirigido necesariamente a la procreación.

El informe de la Comisión Warnock expresa con claridad los valores sociales que subyacen a ese "deseo" por una paternidad biológica mediante una maternidad tecnificada. La Comisión se declaró a favor de la fecundación artificial porque:

"El no tener hijos incluso para aquellos que han optado por no tenerlos, puede ser una fuente de tensión. Parientes y amigos frecuentemente esperan que una pareja constituya una familia (start a family) y manifiestan esta expectativa abierta o veladamente. La familia es una institución valorada en nuestra sociedad: dentro de ella el niño es criado y protegido durante su prolongado periodo de dependencia. Es también en ella donde el niño aprende la conducta social, desarrolla su propia identidad y autoestima... Además de la presión social para tener hijos está también para muchos el deseo intenso de perpetuar sus propios genes a través de una nueva generación. Este deseo no puede ser satisfecho por la adopción" (Warnock, 1985: 8-9).

O, como un editorial de la revista científica Nature recientemente pretendía justificar el alquiler de úteros prohibido por el momento en Inglaterra:

"Los instintos procreativos tienen un significado adaptativo para todas las especies $y$, mientras que pueden convertirse en un problema en sociedades humanas con una esperanza de vida larga, no pueden ser reprimidos por la ley. Además, es natural que haya parejas que prefieran hijos genéticamente vinculados a ellas a aquellos que no lo son. El concepto de gen egoísta de Dawkin, para no mencionar una buena parte de la sociobiología, se refiere a esto" (Nature, 1986: 95).

\section{UNA NUEVA REGLAMENTACIÓN PARA LA VIEJA PATERNIDAD}

La fecundación artificial por donante, no obstante, permite que personas solas, fuera del ámbito familiar, puedan ser madres o incluso padres. La 
Comisión Warnock se opone a esta posibilidad porque: "Como regla general es mejor para los niños nacer en una familia donde la madre y el padre estén presentes, aunque hay que reconocer que es imprevisible su estabilidad" (Warnock, 1985: 11-12).

La Comisión Warnock subordina el deseo individual por un hijo a los valores familiares tradicionales y a los intereses del niño a nacer. La Comisión Benda, de la República Federal de Alemania, acepta la FIV sólo en casos excepcionales de parejas no casadas y la rechaza para individuos solos. En cambio, la Comisión parlamentaria española es bastante más liberal al recomendar que se permita la gestación de mujer sola ${ }^{33}$. Pero cabe interrogarse si esta permisividad mayor realmente pone en cuestión los valores reproductivos vigentes y si, por otra parte, concede a las mujeres solas que optan por una maternidad una mayor libertad para gestionar su capacidad reproductiva.

La familia basada en el matrimonio ha constituido el marco institucional históricamente apropiado de la reproducción de la desigualdad social en la sociedad de clases. En vista del espíritu familiar de esta sociedad, de las dificultades económicas reales de una mujer para criar un hijo sola y del coste de estos procedimientos de fecundación artificial que, según aconseja la Comisión Especial de Estudio, deberían ser realizados siempre por especialistas en clínicas capacitadas para ello, es improbable que muchas mujeres solas hagan uso de estas técnicas. Esto disminuye considerablemente el riesgo de que la maternidad por una mujer sola

\footnotetext{
${ }^{33}$ Como dice el Informe de la Comisión Especial de Estudio: "Se ha tenido en cuenta en la Comisión el componente humano en el deseo de maternidad, entendiéndolo además como un derecho de la mujer a tener hijos, que en cualquier caso y al igual que el hecho biológico del embarazo, nos parece más importante que la donación de gametos" (Congreso de los Diputados, 1985b: 125).

La Comisión apoya esta postura favorable a la gestación de mujer sola en la Constitución según la cual no hay objeción a la adopción por mujer sola ni se discrimina a la madre soltera. Pero recomienda también que se den "razonables garantías para el hijo de que la madre va a ser capaz de educarle, sustentarle e integrarle familiar y socialmente" Congreso de los Diputados, 1985b: 129). Queda por ver, claro, quién y en qué términos va a determinar esta cualificación materna. Por otra parte, la Comisión recomienda que no se autorice la realización de fecundación artificial por las diferentes técnicas en parejas homosexuales aunque la permite para mujeres lesbianas.

En la votación del Informe por el Congreso de Diputados, sin embargo, el diputado Isaías Zaragoza, en nombre del Grupo Popular, se opuso a que la inseminación artificial pueda ser utilizada por mujeres no casadas, aspecto en que coincidió con él la representante del grupo vasco Ana Gorroño, que había participado de la Comisión, defendiendo los intereses del niño por nacer (EI País, 11 de abril de 1986). Ver: Bundesrepublik Deutschland, 1985: 44 yss.
} 
erosione los cimientos de la institución familiar. Además, siempre han existido madres solteras. La cuestión básica ha sido siempre reglamentar su condición y la de los hijos para evitar conflictos patrimoniales.

Aunque haya que relativizar las consecuencias de las nTR para la institución de la familia, no se debe menospreciar el efecto que tienen para la concepción biológica de la procreación en que ésta se basa. No ha de sorprender que la Iglesia y la derecha se opongan a esta intervención tecnológica en el proceso de creación de vida como se oponen a la contracepción y al aborto por atacar éstos al matrimonio y a la familia entendidos como instituciones de derecho natural y divino cuyo fin último es la procreación natural. Tampoco ha de sorprender que el Estado quiera reglamentar estas técnicas en sus efectos legales. Si acaso, la derecha puede aceptar que una mujer sea inseminada artificialmente con el semen del marido, aunque la masturbación requerida para ello plantee problemas morales, pero de ninguna manera puede consentir la fecundación con semen de donante, pues esto constituiría iadulterio! Como argumentaba el catedrático de derecho Balcells Gorina, del Opus Dei, ya en 1980, "los bancos de semen [suponen] verdadera deshumanización -sic- de la paternidad" (Balcells Gorina, 1980). Humano es sólo aquello que es "natural", lo natural es de origen divino y, por tanto, no le cabe al hombre interferir en ello. No obstante, en este conflicto entre razón divina y razón científica la Iglesia tiene las de perder. Las comisiones de estudio de las nTR creadas a nivel nacional e internacional fueron establecidas no para frenar los avances científicos y tecnológicos en el campo de la procreación, sino para reglamentarlas en sus aspectos técnicos, legales y morales en función de sus finalidades socioeconómicas.

Las nTR tienen dos dimensiones. Por una parte, está la ingeniería genética para la cual son un prerrequisito las técnicas reproductivas y especialmente la FIVTE, que hacen posible la manipulación de material reproductivo para la experimentación genética. La Comisión Especial de Estudio recomienda que sean prohibidas las "desviaciones no deseables" de las nTR - concretamente la donación, la ectogénesis, la gestación humana en otras especies y la producción para la experimentación de embriones viables (Congreso de los Diputados, 1985b: 101-102). Todas estas técnicas permitirian eventualmente producir en laboratorio seres humanos a medida. Pero la Comisión también aconseja que estas restricciones no "nieguen amplitud a la ciencia", es decir, no se 
constituyan en obstáculos reales para los intereses de la comunidad científica de avanzar en el control de los procesos de creación de vida. Y de hecho, la Comisión recomienda toda aquella investigación y experimentación cuya finalidad consista en perfeccionar la reproducción que sirva para "corregir la esterilidad humana" y "vaya dirigida a proteger la familia" (Congreso de los Diputados, 1985b: 100; 66; 33), a saber, sobre origen, fases precoces y desarrollo de la vida humana, sobre fertilidad masculina y femenina, sobre fenómenos de rechazo entre semen $y / 0$ embriones y el medio vaginal, del cuello o del cuerpo uterino, sobre anticoncepción y, finalmente, sobre el origen del cáncer (Congreso de los Diputados, 1985b: 100) en el marco de las cuales es posible también la investigación genética y cuyo laboratorio principal es el cuerpo de las mujeres.

Puede parecer contradictoria la permisividad de la Comisión ante la gestación por mujeres solas y la insistencia con que ella justifica las nTR en función "del bien social que es la institución familiar" en términos análogos a la Comisión Warnock (Congreso de los Diputados, 1985b: 34). La Comisión es evidentemente consciente de esta posible contradicción en la medida en que propone reconciliar ambos principios, el derecho de la mujer sola a tener un hijo y la protección constitucional de la familia, defendiendo como "ámbito necesario" para la fecundación artificial "la pareja heterosexual estable" no fundamentada únicamente en el matrimonio y reglamentando la filiación (Congreso de los Diputados, 1985b: 35).

La cuestión de fondo es "quién es el padre". Para las mujeres, las nTR inciden sobre todo en su vivencia de la esterilidad, mientras que para los hombres pueden poner en cuestión la paternidad. Una relativa autonomía reproductiva por parte de las mujeres es posible sólo en el caso de la IA, pero la Comisión recomienda que incluso ésta sea controlada por especialistas. Además, la Comisión entiende que para las mujeres la gestación es más importante que el vínculo genético como hecho acreditativo de la maternidad y desaconseja la maternidad por sustitución -el "alquiler de útero"- porque podría implicar posible concurrencia de maternidades, es decir, disolver la maternidad individual (Congreso de los Diputados, 1985b: 41 y 166). En lo que se refiere a la paternidad, las recomendaciones de la Comisión consisten en una consagración, en las nuevas circunstancias creadas por la nTR, de una vieja realidad. Si, por una parte, "deberá regularse que el matrimonio o 
pareja estable a cuya mujer se realice una IAD o una FIV con semen, óvulos o embriones de donantes -...consentidas por ambos miembrosserán los padres legales del o de los hijos que nazcan", por otra, el varón estable de una pareja a cuya mujer se ha realizado una fecundación con material de donante sin su consentimiento podrá renunciar al hijo así nacido que será registrado como sin padre (Congreso de los Diputados, 1985b: 164) ${ }^{34}$. Es decir, mientras que la mujer se somete a las manipulaciones de la fecundación artificial, es el hombre el que tiene la última palabra sobre la paternidad.

Así, las nTR no constituyen para las mujeres ninguna opción nueva. Al contrario, son un nuevo instrumento de manipulación ideológica, psíquica y física, desarrollado y utilizado en función de intereses que no son los suyos. Los políticos se alarman ante el descenso de la natalidad, los científicos y los técnicos se afanan por conquistar los últimos secretos de la vida, los hombres quieren tener hijos "propios", y el Estado se preocupa por asegurar la nueva vieja paternidad. Las mujeres, en cambio, no sólo no controlamos nada, sino que somos los objetos, imprescindibles además, de toda esta manipulación.

\section{PosdatA A LA EDICIÓN DE 2018}

Como señalaba Strathern (1993), el sexo y la procreación, las fuentes de la vida, aparte de la muerte, están entre las materialidades más gloriosas, ricas e intensamente simbolizadas y emocionalmente cargadas de la experiencia humana. De modo que aunque lo que se manipule en el laboratorio sea un material reproductivo incorpóreo (óvulos, espermas, embriones) estas manipulaciones biotecnológicas están cargadas de significados socio-culturales y efectos. Y surgen vínculos entre vínculos, a saber, entre aquellos creados en el ámbito de los hechos naturales y aquellas relaciones sociales engendradas y sus significados culturales. En este articulo, que publiqué en 1988, presento un relato sencillo de cómo se desarrolló la medicalización de la procreación humana y sus condicionantes y consecuencias socio-culturales a lo largo de los pasados dos siglos. Las técnicas de reproducción asistida incluyendo la fecundación in vitro con material de donante no alteraba

\footnotetext{
${ }^{34}$ En realidad, lo que se está recomendando aquí es que el hombre pueda repudiar a ese hijo, es decir, desentenderse de cualquier obligación ante él. Se está introduciendo así una especie de "adulterio tecnológico".
} 
cualitativamente los hechos de la vida básicos, esto es, la reproducción sexual como una característica de los mamíferos.

La sensacional noticia en febrero de 1997 de la creación de Dolly, el primer mamífero clonado de una célula adulta acercaron como nunca antes a los biotecnólogos a rediseñar nuestra propia especie. Dolly ilustraba la búsqueda incesante por trascender los propios hechos de la naturaleza. La creación en el laboratorio de seres humanos mejorados genéticamente en el siglo XXI, proclamado como el "siglo de la biotecnología", parecía algo cada vez más probable a la postre del celebrado nacimiento de Dolly (Freundlich, 1997; Craig Venter y Cohen, 1997).

La oveja Dolly fue un auténtico adelanto biotecnológico. Ian Wilmut, el creador de Dolly y su equipo en el Roslin Institute, Escocia, lograron hacer retroceder el reloj biológico del núcleo de una célula somática adulta al estado primitivo pluripotente de manera que era posible que el núcleo de la célula somática se diferenciase de nuevo, resultando en un organismo enteramente nuevo, un clon. Pero Dolly era, además, una oveja común y corriente, excepto por su concepción. La segunda primicia de Wilmut y su equipo fue la hazaña de una inmaculada concepción en mamíferos. La concepción de Dolly tuvo lugar en el laboratorio no solamente sin coito, sino sin espermatozoides ${ }^{35}$. La descripción del procedimiento en internet capturó bien la naturaleza biotecnológica del mismo:

"Para clonar a Dolly Wilmut y su equipo cosechó una célula mamaria de una oveja de seis años; retiró el núcleo de una célula de un óvulo de otra oveja e introdujo el núcleo de la célula mamaria en el óvulo enucleado; a seguir, Wilmut aplicó una pequeña descarga eléctrica en las dos células $y$, para la sorpresa general, éstas se comportaron como un óvulo fertilizado comenzando a diferenciarse empleando el ADN de la célula mamaria como instrucción genética; y a continuación Wilmut implantó el embrión en otra oveja portadora, y en pocos meses nació Dolly, una copia genética 'exacta' de la oveja donante de la célula mamaria" (Mario, 1997) ${ }^{36}$.

\footnotetext{
${ }^{35}$ Publiqué un primer análisis de las implicaciones biotecnológicas de la clonación en el género en Stolcke, 1998.

${ }^{36}$ Pero The Economist escribió en ese tiempo: "Un obstáculo en la ingeniería de grandes animales es que la técnica más revolucionaria transgénica en el ratón -llamada tecnología embriónica de la célula madre- no funciona en muchas otras especies de mamíferos. El trasplante nuclear, la inmaculada concepción de Dolly, puede ser una de las formas de sortear esta barrera en ovejas y otras especies" (The Economist, 1997: 81).
} 
El resultado fue una copia genética exacta de la hembra donadora de la célula somática, ya que Dolly también heredó el ADN de sus mitocondrias. Dolly fue una oveja normal excepto por su concepción. Dolly tuvo tres madres pero ningún padre.

Aunque el procedimiento de clonación embrionaria sea el mismo, para reducir los temores ante abusos, se distingue entre la clonación reproductiva y la clonación terapeútica. La primera consiste en la reproducción de organismos idénticos enteros, que se emplea ahora en la cría de animales pero que está radicalmente rechazada por razones éticas en humanos aunque incluso científicos no la consideran enteramente inconcebible ${ }^{37}$. La clonación terapéutica consiste, en cambio, en obtener células madre de un embrión clonado para cultivar órganos para trasplantes que no provoquen rechazo inmunológico en la nueva medicina regenerativa, pero se cuestiona porque en el proceso se destruye el embrión.

Las nTR han transformado el modo en que y hasta qué punto las personas pueden decidir sobre su reproducción de forma radical. La selección sexual del bebé por motivos socio-culturales más que médicos ya se practica hace algún tiempo. Además, la propia comunidad científica ha reconocido el potencial eugenésico de las nTR y se interroga hasta qué punto la edición genética ${ }^{38}$ que se ha refinado en la pasada década está

\footnotetext{
${ }^{37}$ A la vuelta del milenio, científicos británicos creyeron que la clonación reproductiva humana era inevitable. Más de la mitad de un panel de 32 científicos encuestados por el periódico británico The Independent, anticiparon que la clonación reproductiva se intentaría dentro de 20 años (Connor, 2000).

${ }^{38}$ La tecnología CRISPR es una reciente herramienta de edición del genoma que actúa como unas tijeras moleculares capaces de cortar cualquier secuencia de ADN del genoma de forma específica y permitir la inserción de cambios en la misma (Genetic Medical News, 2018): "Genome editing is the deliberate alteration of a selected DNA sequence in a living cell. A strand of DNA is cut at a specific point and naturally existing cellular repair mechanisms, then fix the broken DNA strands. The way they are repaired can affect gene function and new DNA sequences can be delivered when the DNA is cut and act as templates for generating an altered sequence. Genome editing techniques can be used to delete sections of DNA or alter how a gene functions: for example, by changing a variant that may give rise to disease to one that functions normally. Genome editing techniques make use of certain proteins that can cut DNA in a precise, targeted location. Although this family of proteins was discovered in the 1960s, it is only since around 2005 that the ability of some of them to make precisely targeted cuts at almost any position in the genome has been recognized and utilized by scientists. Among the recent genome editing technologies, CRISPR-based methods are particularly promising owing to their relative efficiency, low cost; and ease of use, and the prospect of making edits at multiple sites in the genome in a single procedure" (Nuffield Council of Bioethics, 2016).
} 
abriendo la puerta de atrás a la eugenesia. (Christiansen, 2017). En efecto, en un mundo progresivamente más desigual y nacionalista, fragmentado por viejas y nuevas jerarquías de valor social, la reproducción humana selectiva amenaza con trascender el ámbito de la ciencia ficción.

La ciencia y la tecnología se desarrollan en un entorno histórico con estructuras de poder, intereses económicos y ambiciones científicas, así como deseos y expectativas individuales que las inspiran. Así, el genetista francés y miembro del Comité Nacional Consultivo de Ética Axel Kahn, en una carta dirigida a la revista Nature solicitó en 1997 que se esperara con la publicación del protocolo de lan Wilmut en el que documenta los detalles biotecnológicos de la clonación de la oveja Dolly, para ganar tiempo para llevar a cabo una rigurosa evaluación ética de las perspectivas de que se realice una clonación en seres humanos. Como insistió Kahn:
"Ante la poderosa tendencia social y psicológica entre las personas hoy día hacia un deseo fanático no sólo de tener hijos sino de asegurar que esos hijos sean portadores de sus genes incluso en el caso de infertilidad (o muerte)... hay en la sociedad una demanda creciente por la herencia biológica, como si ésta fuese la única forma de herencia que merece tal nombre. Una razón lamentable es que la personalidad de los individuos se percibe cada vez más como determinada primordialmente por los genes" (Kahn, 1997: 1-4).

Kahn opinaba que este deseo fanático de tener descendencia biológica podía convertirse en una razón poderosa para llevar a cabo la clonación de bebés humanos, en especial en casos de esterilidad masculina severa como la displasia o atrofia testicular para asegurar la vieja paternidad.

Sin embargo, el que la clonación en mamíferos fuese en un principio un procedimiento asexual de fecundación, un monopolio femenino en el que el varón resultaba superfluo, pasó no sólo inadvertido para Kahn sino para la opinión pública así como para los medios de comunicación en general. Así, una mujer entrevistada en el Reino Unido en el marco de una encuesta pública exclamó sorprendida "estoy totalmente confundida ¿qué ocurre con los hombres- cómo puedes tener un bebé sin un hombre?". Otra se preguntaba cómo sería "hacerte adulta y que te digan que no tienes padre, en un sentido genético". Y aún otra entrevistada hizo hincapié en la "redundancia masculina" (The Wellcome Trust, 1998). Ese monopolio femenino en la clonación reproductiva persistió poco tiempo. En 1999, dos investigadores de la Escuela de Medicina de la Universidad 
de Hawaii, Honoloulu, lograron clonar el primer mamífero macho, un ratón, Ilamado Fibro (Abdulla, 1999). En contraste con Dolly y los numerosos otros animales que se clonaron con el ADN de una hembra adulta o un embrión, Fibro fue engendrado con células cosechadas de un ratón macho adulto, es decir, de células "ordinarias". Como explicaron estos investigadores, ellos inyectaron el núcleo de esas células "ordinarias" en óvulos de ratón enucleados. La tasa de éxito fue, como de costumbre en estos experimentos, baja pero un ratón llamado Fibro, sobrevivió para convertirse en un macho adulto fértil. De este modo, como pronosticaba Kahn, la clonación reproductiva masculina podrá eventualmente ofrecer una cura de formas extremas de infertilidad masculina.

Sin extenderme en los detalles biotecnológicos querría subrayar tan sólo el impulso sin duda nuevamente bio-cultural que permitió superar la redundancia masculina de la clonación inicial. Al subrayar el atractivo genealógico que podría poseer la clonación reproductiva en una sociedad como la occidental moderna que concibe los vínculos de parentesco en términos biogenéticos, se suele confundir, además, la descendencia del óvulo cuyo núcleo contiene el ADN a ser reproducido, con el hecho de que se trata de una réplica, es decir, un gemelo idéntico de la donante. La noción occidental del parentesco es, sin embargo, bilateral, por lo que la clonación que es unilateral, contradiría nuestras arraigadas nociones de descendencia.

Otro ejemplo del poder que puede ejercer la cultura en la biología son los experimentos de fecundación asistida denominada singamia que se comenzaron en 2002. El objetivo de esta técnica reproductiva es obtener un embrión engendrado por una semi-clonación (la unión por coalición del núcleo del gameto de un progenitor y el núcleo de una célula somática de una progenitora para formar un cigoto) para superar el origen genético uni-parental en el caso de la clonación original. Se engendraría así un embrión, biparental, que respetaría la concepción occidental bilateral del parentesco (Tesarik, 2002). Clones masculinos serian relevantes a este respecto.

François Jacob, el premio Nobel en medicina (1965), consideró la fecundación asexual de la clonación de la oveja Dolly en su momento con un guiño irónico antropológico:

“Por mucho tiempo intentamos tener placer sin niños. Con la fertilización in vitro tenemos niños sin placer. Y ahora hemos 
llegado a producir niños sin placer y sin espermatozoides... Evidentemente esto cambia la estructura familiar un poco... Por el momento, al menos entre las ovejas" (Nodé-Langlois y Vigy, 1997).

En vista de algunas de las novedades biotecnológicas reproductivas que he descrito arriba tiendo a dudar, no obstante, del poder que François Jacob le atribuye a la biología de transformar las estructuras socioculturales.

\section{BibLIOGRAFÍA}

AA. VV. (1985). Génétique, procréation et droit. Actes du colloque. Arles: Actes Sud.

Abdulla, S. (1999). First male clone. Nature, 3 de junio. Disponible en: https://www.nature.com/news/1999/990603/full/news990603-

2.html.

Allen, G. E. (1970). Science and Society in the Eugenic Thought of H. J. Muller. Bioscience, 20(6), 346-353.

Amorós, C. et al. (1987). Mujeres: ciencia y práctica política. Madrid: Universidad Complutense de Madrid.

Balcells Gorina, A. (1980). La inseminación artificial, zootecnia en el hombre. La Vanguardia, 3 de mayo.

Barri Rague, P. N. (1985). Comisión especial de estudio de la fecundación "in vitro" y la inseminación artificial humanas. En VV. AA., Diario de Sesiones del Congreso de los Diputados, 357, 10906-10926.

Bundesrepublik Deutschland (1985). Bericht der Arbeitsgruppe In-vitro Fertilisation, Genornanalyse und Gentherapie. Benda-Kommssion des Bundestages (Bonn), 25 de noviembre.

Catalán Deus, José (1986). ¿Tener hijos? No, gracias. El País, 23 de marzo (suplemento dominical).

Christiansen, K. (2017). Genome editing: Are we opening a back door to eugenics? Science Nordic, 14 de noviembre. Disponible en: http://sciencenordic.com/genome-editing-are-we-opening-backdoor-eugenics.

Clarke, A. (1984). Subtle Forms of Sterilization Abuse: a Reproductive Rights Analysis. En R. Arditti, R. Duelli Klein y S. Minden (Eds.), TestTube Women (pp. 188-203). Londres: Pandora Press. 
Congreso de los Diputados (1985a). Comisión especial de estudio de la fecundación "in vitro" y la inseminación artificial humanas. En Diario de Sesiones del Congreso de los Diputados, 357: 10906-10926.

Congreso de los Diputados (1985b). Informe de la Comisión Especial de Estudio de la Fecundación "in Vitro" y la Inseminación Artificial Humanas. En Diario de Sesiones del Congreso de los Diputados, 334.

Congreso de los Diputados (1985c). Informe de la Comisión Especial de Estudio de la Fecundación "in Vitro" y la Inseminación Artificial Humanas. En Diario de Sesiones del Congreso de los Diputados, 346.

Congreso de los Diputados (1986). Informe de la Comisión Especial de Estudio de la Fecundación "in Vitro" y la Inseminación Artificial Humanas. En Diario de Sesiones del Congreso de los Diputados, 280, 12554-12579.

Connor, S. (2000). Human Cloning is now inevitable. The Independent, 30 de agosto.

Corea, G. (1984). Egg snatchers. En R. Arditti, R. Duelli Klein y S. Minden (Eds.), Test-Tube Women (pp. 37-51). Londres: Pandora Press.

Corea, G., e Ince, S. (1987). Report of a survey of IVF clinics in the US. En P. Spallone y D. Lynn Steinberg (Eds.), Made to Order; The Myth of reproductive and Genetic Progress (pp. 133-145). Oxford: Pergamon Press.

Craig Venter, J., y Cohen, D. (1997). A las puertas del siglo de la biología. El Pais, 18 de junio.

Crowe, C. (1985) Women want it: In-Vitro Fertilization and Women's Motivations for Participation. Women's Studies Int. Forum, 8(6), 547552.

David, G. (1985). Don et utilisation du sperme. En AA. VV., Génétique, procréation et droit. Actes du colloque (pp. 202-224). Arles: Actes Sud.

Debré, M. (1979). Entrevista. Le Nouvel Observateur, 30 de abril.

Deutsches Aerzteblatt (1986). Ausgabe B. Band, 83(7), 14 de febrero.

Duelli Klein, R. (1985). What's 'new' about the 'new' reproductive technologies? En G. Corea et al. (Eds.), Man-Made Women (pp. 6473). Londres: Hutchinson.

Duelli Klein, R. (1986). The crucial role of in-vitro fertilisation in the social control of women. GRAEL y FINRRAGE (Coords.), Women's Hearing in Genetic Engineering and Reproductive Technologies. Bruselas: Mimeo. 
Freundlich, N. (1997). The Biotech Century. Special Report. Business Week, 10 Marzo, 78-92.

Genetic Medical News (2018). Category CRISPR. Genetic Medical News, 5 de febrero.

Gomez dos Reis, A. R. (1985). IVF in Brazil: the story told by the newspapers. En P. Spallone y D. Lynn Steinberg (Eds.), Made to Order; The Myth of reproductive and Genetic Progress (pp. 120-132). Oxford: Pergamon Press.

Gordon, L. (1976). Woman's Body, Woman's Right. Londres: Penguin Books.

Héritier-Augé, F. (1985a). La Cuisse de Jupiter, Réflexions sur les nouveaux modes de procréation. L'Homme, 94(2), 5-22.

Héritier-Augé, F. (1985b). L'individu, le biologique et le social. Le Debat, $36(4), 27-32$.

Jayaraman, K. S. (1986). India Embraces Test-Tube Babies. Nature, 319, 611.

Kahn, A. (1997). Clone Mammals-Clone Man? Nature, 385, 1-4.

Labourie, F. (1986). Juridical and ethical aspects of genetics engineering. En GRAEL y FINRRAGE (Coords.), Women's Hearing in Genetic Engineering and Reproductive Technologies. Bruselas: Mimeo.

Leal, J. L. (1986). El descenso de la tasa de natalidad. El País, 5 de abril.

Lesourne, J. (1986). La inmigración, una dimensión nueva del siglo XXI europeo. El País, 22 de marzo.

Mario, C. (1997). A spark of science, a storm of controversy. Princetoninfo, 1-6.

Mies, M. (1985). Why do we need all this? A call against genetic engineering and reproductive technology. Women's Studies Int. Forum, 8(6), 553-560.

Ministerio de Justicia (1986). Problemas civiles que plantea la inseminación artificial y la fecundación "in vitro". Boletín de Información del Ministerio de Justicia, 3.

Muller, H. J. (1936). Out of the Night. A Biologist's View of the Nature. Londres: Victor Gollancz Ltd.

Nature (1986). Tough talk on surrogate birth. Nature, 13 de marzo de 1986.

Nodé-Langlois, F., y Vigy, M. (1997). François Jacob, 'Faire des enfants sans plaisir ni spermatozoide'. Le Figaro, 27 Febrero. 
Nuffield Council of Bioethics (2016). Genome editing in brief: what, why and how? Disponible en en: http://nuffieldbioethics.org/report/genome-editing-ethicalreview/genome-editing.

Rivière, P. (1985). Unscrambling Parenthood: The Warnock Report. Anthropology Today, 1(4), 2-7.

Rosanova, V.D. (s/f). Artificial insemination: the views of Soviet women and physicians. Inédito.

Shapiro, J. (1986). La antropología y el estudio del género. En E. Langland (Comp.), La actuación femenina en el mundo académico (pp.153178). Buenos Aires: Fraterna.

Singer, P. (1986). La revolución reproductiva. El País, 14 de junio.

Stolcke, V. (1982). Los trabajos de las mujeres. En M. León (Ed.), Debate sobre la mujer en América latina y el Caribe (pp. 11-31). Bogotá: ACEP.

Stolcke, V. (1988). New reproductive Technologies: The old quest for fatherhood. Reproductive and Genetic Engineering, 1, 5-19.

Stolcke, V. (1998). El sexo de la biotecnología. En A. Durán y J. Riechmann (Comps.), Genes en el laboratorio y en la fábrica (pp. 97-118). Madrid: Trotta y Fundación $1^{\circ}$ de Mayo.

Strathern, M. (1993). Entangled objects: Detached metaphors. Social Analysis: The International Journal of Social and Cultural Practice, 34, 88-101.

Symons, D. (1980). The Evolution of Human Sexuality. Oxford: Oxford University Press.

Tesarik, J. (2002). Reproductive semi-cloning respecting biparental embryo origin. Embryos from syngamy between a gamete and a haploidized somatic cell. Human Reproduction, 17(8), 1933-1937.

The Economist (1997). "Present company not included?": Genetic Engineering. Building to Order. The Economist, 1 de marzo.

The Welcome Trust. England London Medicine in Society Programme (1998). Public Perspectives on Human Cloning. A Social Research Study. Londres: The Trustee of The Welcome Trust.

Thibault, O. (1985). Réflexions d'une Femme Biologiste et Féministe. En VV. AA., Génétique, procréation et droit. Arles: Actes Sud.

Warnock, M. (Ed.) (1985). A question of Life: Warnock report on Human Fertilization and embryology. Londres: Blackwell. 
Webster, C. (Ed.) (2003). Biology, Medicine and Society, 1840-1940. Cambridge: Cambridge University Press.

Woolf, Virginia (2014). Tres guineas. Barcelona: Lumen. 